\title{
Need Assessment for the Supply of Vocational High School Teachers in Indonesia حStudy on Developmental Issues of Vocational Institute
}

\author{
Radna Andi Wibowo Nyan-Myau Lyau \\ National Yunlin University of Science and Technology, 123 University Road, Section 3, \\ Douliou, Yunlin 64002, Taiwan, R.O.C \\ *Corresponding e-mail: andy_ostborn@hotmail.com
}

\begin{abstract}
This research purpose is to specify the needs of vocational schoolteachers or instructors and recognize the efforts to comply with vocational schoolteachers/instructors' requirements. This study accustomed a quantitative approach with a secondary data analysis method. This research indicates that the needs of specialized vocational teachers and instructors possibly classified as a deficiency in both private and state schools. In contrast, the lack of private schools is higher than in-state schools. Efforts to comply with the specialized vocational instructors have been undertaking by the Indonesian government, containing: Hiring of teacher's public officials, hiring of Honorary instructors, and the Dual Expertise Program.
\end{abstract}

Keywords:Vocational Schoolteachers, Private and State school, Vocational Specialization Teachers, Vocational High Schools, Meeting Teacher Needs.

DOI: $10.7176 / \mathrm{JEP} / 12-11-02$

Publication date: April $30^{\text {th }} 2021$

\section{Introduction}

It has been the aspiration of human societies, both developed and developing, to provide education for all as an inherent human right. In the last three decades of the twentieth century and into the twenty-first century, we have witnessed countries relying on education to bolster their economic and social development. Increasing access to education through expansion has been a global trend, yet unbalanced development in different levels of education has created many problems as well. Almost all countries, including Indonesia, are very interested in increasing economic growth.

High economic growth is believed to reflect an increase in people's welfare. To increase economic growth, a strategy that is considered effective is industrialization. Industrialization, to a certain degree, implies a shift in the production process from labouring to manufacturing in the sense that human labour is replaced by hard technology. This means that industrialization requires skilled workers who can not only operate the technology but also maintain it. Industrialization also has the potential to create unemployment if the shift in the production process is not accompanied by a change in educational orientation from academic to vocational. Therefore, in order to support economic growth, education such as vocational schools is important (Jose Rizal Joesoef, Umi Muawanah, Fahmi Poernamawati and Mukhlis, no date).

For many years, the Indonesian government tried to encourage the development of vocational schools, evidenced by the increasing number of vocational schools. Luckily, community interest in especially parents welcomed this intention by sending their children to vocational schools. Figure (1) \& (2) showing what the researcher said:

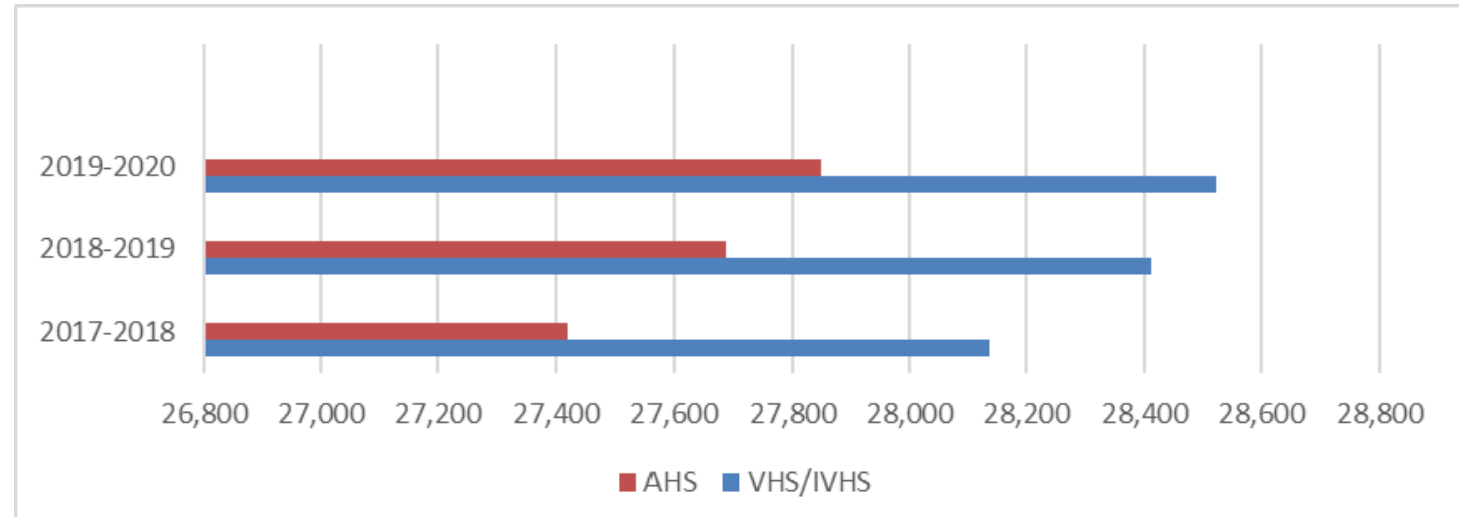

Figure 1. The number of VHS and AHS in Indonesia 


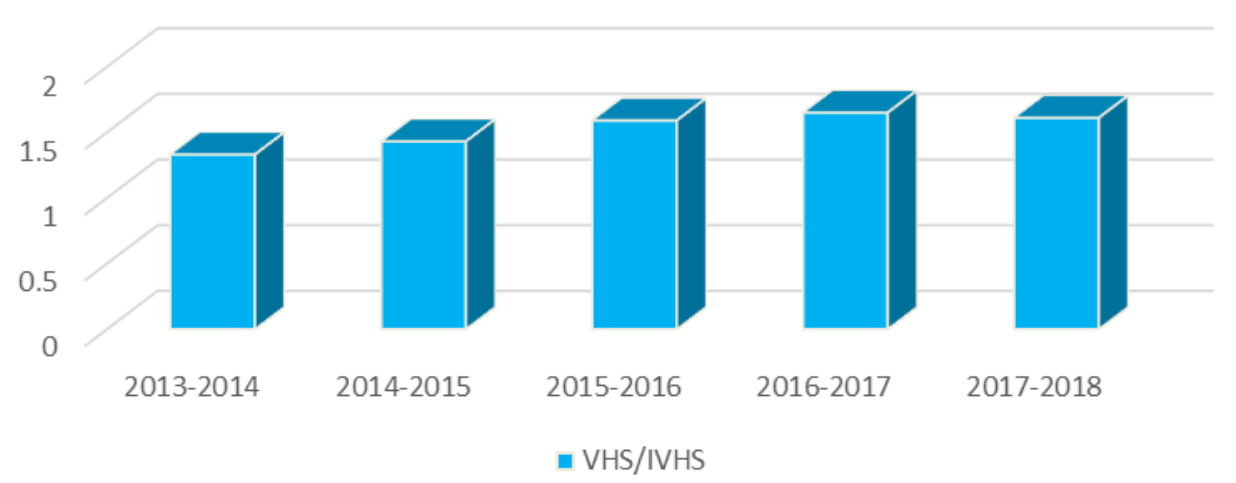

Figure 2. The Number of New Student from 2013-2018 (In Million).

One of the instructions of the Presidential Instruction No. 9 of 2016 concerning the Revitalization of Vocational High Schools in Improving the Quality and Competitiveness of Indonesian Human Resources is to increase the number and competence of educators and staff of Vocational High Schools (VHS). The presence of teachers is very important so that the availability of teachers must be sufficient, given their existence to support the main tasks of educating, teaching, guiding, directing, training, assessing, and evaluating students in early childhood education through formal education, basic education, and secondary education. Many variables that impact students' academic achievement, none has elicited as much attention and controversy as teachers. Policy makers, school administrators and parents regard teacher quality and quantity as central to improved students' performance although research data is inconsistent (Munene and Ruto, 2016).

Teacher shortages have an impact on the quality of education, especially in the quality of the process and the quality of graduates. The availability of sufficient teachers is the main key to the continuity of good learning in every educational institution. The term teacher shortage is used to refer to an insufficient production of new teachers, given the size of student enrolment and teacher retirements. In this narrow definition, a teacher shortage is measured only by teacher production in relation to these factors associated with teacher demand. Nonetheless, a large body of research indicates that teacher staffing problems are driven by a myriad of factors, including not only production of new teachers in various fields, but also teacher turnover, changes in educational programs and

pupil-teacher ratios, and the attractiveness of teaching generally and in specific locations (Sutcher, DarlingHammond and Carver-Thomas, 2019).The published estimates of the increasing teacher shortage further understate the magnitude of the problem because the estimates don't reflect the fact that the shortage of qualified teachers is not spread evenly among all schools but is more acute in high-poverty schools(García, Emma and Weiss, 2019).

At present, the spectrum and curriculum of VHS have changed. Regulation of the Director General of Primary and Secondary Education Ministry of Education and Culture Number: 06 / D.D5 / KK / 2018 Regarding About the Vocational High School (VHS) / Madrasah Aliyah Vocational (IVHS) Expertise Spectrum, states that the areas of expertise in VHS / IVHS include; (1) Technology and Engineering, (2) Energy and Mining, (3) Information and Communication Technology, (4) Health and Social Work, (5) Agribusiness and Agrotechnology, (6) Maritime, (7) Business and Management, (8) Tourism, and (9) Arts and Creative Industries. Of the nine areas of expertise, these are translated into 49 expertise programs and 146 expertise competencies (Table 1).

Table 1. Expertise Spectrum at Vocational High School/ Islamic Vocational High School

\begin{tabular}{|c|c|c|c|}
\hline No & Areas of expertise & $\begin{array}{c}\text { Number of Expertise } \\
\text { Programs }\end{array}$ & $\begin{array}{c}\text { Number of Expertise } \\
\text { Competencies }\end{array}$ \\
\hline 1. & Technology and Engineering & 6 & 58 \\
\hline 2. & Energy and Mining & 3 & 6 \\
\hline 3. & $\begin{array}{c}\text { Information and Communication } \\
\text { Technology }\end{array}$ & 2 & 6 \\
\hline 4. & Health and Social work & 5 & 7 \\
\hline 5. & Agribusiness and Agrotechnology & 6 & 20 \\
\hline 6. & Maritime Affairs & 4 & 10 \\
\hline 7. & Business and Management & 4 & 7 \\
\hline 8. & Tourism & 4 & 9 \\
\hline 9. & Arts and Creative Industries & 8 & 23 \\
\hline & Total & 42 & 146 \\
\hline
\end{tabular}

In the Regulation of the Director General of Primary and Secondary Education Number: 07 / D.D5 / KK /

2018 it is stated that subjects in VHS / IHVS are grouped into three groups of subjects (Table.4), namely: (1) 
National content (normative), (2) Local content (adaptive), and (3) Content of specialization subject (productive). Associated with vocational specialization teachers, vocational specialization teachers are teachers of vocational content subjects. Vocational specialization teachers used to be called productive teachers (MoEC, 2006).

Table 2. Subject Groups in VHS/ IVHS

\begin{tabular}{|c|c|c|}
\hline No. & Subject Group & Discipline \\
\hline 1. & National Content (Normative) & $\begin{array}{ll}\text { - } & \text { Religion and Manner Education } \\
\text { - } & \text { Pancasila and Civic Education } \\
\text { - } & \text { Indonesian Language Courses } \\
\text { - } & \text { Mathematics } \\
\text { - } & \text { Indonesian History } \\
\text { - } & \text { English Language Courses } \\
\text { - } & \text { Other Foreign Languages } \\
\end{array}$ \\
\hline 2. & Local Content (Adaptive) & $\begin{array}{ll}\text { - } & \text { Cultural Arts } \\
\text { - } & \text { Physical Education, Sport and Health } \\
\end{array}$ \\
\hline 3. & $\begin{array}{l}\text { Content of Specialization } \\
\text { (Productive) }\end{array}$ & $\begin{array}{ll}\text { - } & \text { Basic Field of Expertise } \\
\text { - } & \text { Basic Expertise Program } \\
\text { - } & \text { Expertise Competence }\end{array}$ \\
\hline
\end{tabular}

By observing the mandate of Presidential Instruction No. 9 of 2016 with changes in the perspective and curriculum of vocational schools, changing strongly what is meant by vocational specialization teachers is still being debated. Dapodik (Basic Data for Primary and Secondary Education) as at 2018 December 31 $1^{\text {st }}$, determined the number of teachers specializing in vocational training, between the number of existing teachers and the ideal number of teachers (receiving). At the state Vocational School there are 62,105 teachers, while the ideal number of teachers is 88,091 . In private VHS there are 54,238 teachers, while the ideal number of teachers is 119,513 teachers. For this reason, this article is presented, as part of the results of studies conducted. Explicitly the aim to be known is to know the needs of vocational specialization teachers and suggest alternative efforts to fulfil them.

Based on the data descriptions, this research aims to to determine the needs of Vocational High School teachers and identify efforts to meet the needs of Vocational High Education teachers. Moreover, the research questions are outlined as follows: 1) How many vocational specializations need of teachers (The ideal number of teachers: Current number of teachers)? What are efforts to meet the needs of vocational specialization teachers that have been made?

\section{Literature Review}

\subsection{Teacher in TVET}

Teacher is the heart of the education system where professional teaching standards are used as a set of criteria in determining professionalism of technical teachers. Teacher professionalism and skills influence the progress of their students and are an important component of TVET institutions. A competent teacher will be able to provide quality assurance for student learning (Sulaiman et al., 2019).

Based on (Meng, Zhang and Lan, 2014) The teaching of vocational and technical teacher education refers to developing a qualified vocational school teacher. In addition to mastering a discipline or specialty and having relatively deep and rich scientific and cultural knowledge, the teacher must also receive professional training as a teacher. This means developing a teacher's professional ethics and educational knowledge and skills. The "teaching" aspect is therefore not restricted to pedagogy, educational psychology, or professional methodology. It also includes developing students with good professional ethics and moral character who are proficient in essential teaching techniques, and who love vocational education. The requirements for good instructors in Vocational Education and Training (with pedagogical and technical skills, trained in teacher education institutions and with experience in the labour market) are higher than those for general education, and they are costly to develop or attract (International, 2009).

\subsection{Teacher Shortages}

The problem of teacher shortages cannot be adequately resolved by attending to individual, incoming teachers alone. Rather, issues of power differentials and conflict, alienation, inequitable resource allocation, hopelessness, and fear all take their toll on achieving the desired outcome of recruiting and retaining the necessary number of qualified teachers in classrooms $(\mathrm{Ng}, 2003)$.

Teacher shortages are divided into two levels: (a) the national level, namely the macro level (state, provincial, regional or district), and (b) the school level, namely the micro level. The understanding of teacher shortages that appears at these two levels may not always be the same because of different factors operating at each level. Examples of factors that cause shortages at the national level include growing student population, 
increasing immigration, changes in national education policies and employment agreements, obscuring the workforce, and low professions (Donitsa-schmidt and Zuzovsky, 2016). Several factors leading to shortage at the school level include local school-related factors such as acute discipline problems, lack of support on the part of the principals, lack of teacher autonomy, absence of professional development activities, and a dearth of benefits offered in a particular school (J. King Rice, C. Roelke, D. Sparks, 2009; Cannata, 2010). Even though the factors that operate at the school level do not necessarily affect the overall national balance between supply and demand, but they are responsible for problems caused by imbalances at the school level (Ingersoll and May, 2012).

\subsection{The impact of teacher shortages.}

The problem with shortage of supply is that we put at risk the quality of instruction available to our young people because there is no competition for jobs in some areas. (Triwiyanto, T., Desi Eri Kusumaningrum, 2017) Emphasized that the teacher as a party that is directly related to the learning process in the classroom has an important role in improving the quality of their students. Teachers, both in quantity and quality of teachers are important in shaping the quality of students. This is because the teacher's very strategic role is to educate, teach, guide, direct, train, assess, and evaluate students in early childhood education through formal education, basic education, and secondary education.

The tendency of vocational schools to offer majors and competencies that are easily taught (the need for tools and vocational teachers is minimal), while the demand for these majors is large. This will have an impact on vocational graduates who have no competitiveness and added value compared to high school graduates or college graduates (Yulius, Muhammad Isran, Mardhianda WP, 2017). They also stressed that in terms of quality, $78 \%$ of vocational teachers are normative-adaptive teachers and only $22 \%$ are productive teachers for vocational subjects. With a higher percentage of normative-adaptive teachers than teachers who specifically have competence in their vocational fields, this could be one of the threats to the low competitiveness of Vocational High School graduates. They also stressed that in terms of quality, $78 \%$ of vocational teachers are normativeadaptive teachers and only $22 \%$ are productive teachers for vocational subjects. With a higher percentage of normative-adaptive teachers than teachers who specifically have competence in their vocational fields, this could be one of the threats to the low competitiveness of Vocational High School graduates.

The worst scenario of a severe teacher shortage in the future is stated in "Teacher Exodus - The Meltdown scenario" in the OECD's Education Policy Analysis 2001. This has caused widespread public dissatisfaction with the state of education in the face of a deep teacher-recruitment crisis and a growing sense of declining standards, especially in the worst-affected areas. But the direct impact of a shortage is more likely to be a lower quality of teachers and teaching than a dramatic tale of classrooms full of uninstructed pupils. In the short term, the main mechanism used to balance supply and demand is to relax qualification requirements. Alternatively, demand can be reduced and brought into line with the available supply by increasing teachers' workloads or class sizes. In either case, quality suffers (Paulo Santiago, no date).

Besides that, Vocational High School (VHS) is ranked first in the contributor of open unemployment, then followed by (Academic High School/AHS), Diploma I / II / III, \&and University. Figure 3. presents the percentage of the Open Unemployment Rate.

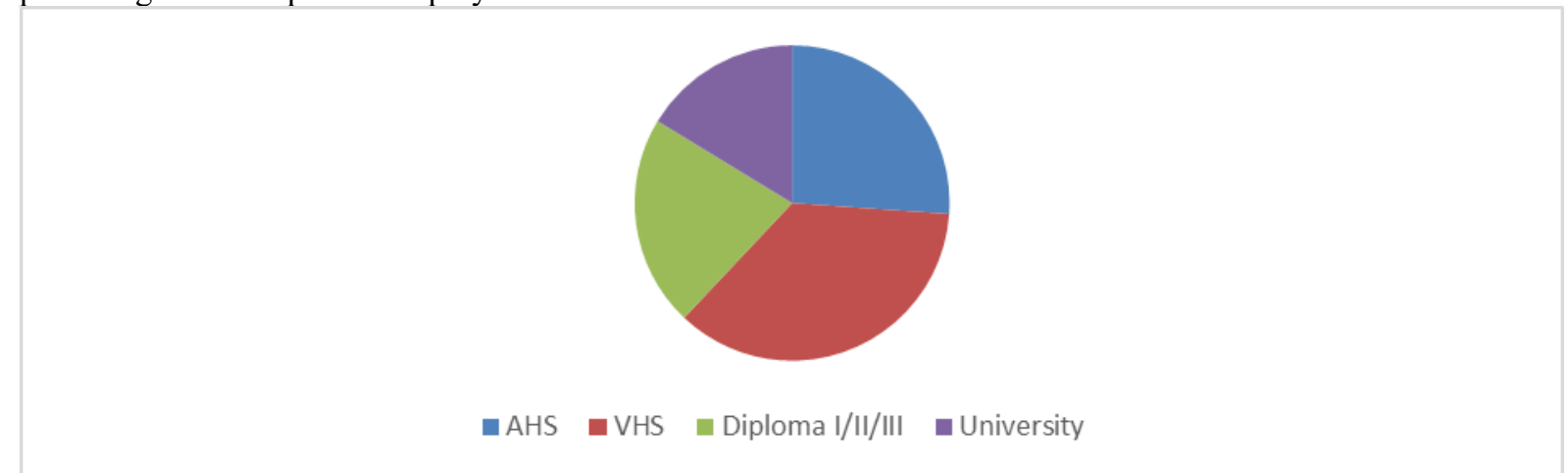

Figure 3. Open Unemployment Rate (TPT) According to the Highest Level of Education Graduated (percent), August 2017 - August 2018

\section{Methodology}

This study was conducted with a quantitative research approach with secondary data analysis methods. Secondary data analysis is a research strategy that utilizing quantitative or data Qualitative existing to find new problems or test results in previous research. (Hinds, P.S., Vogel, R.J., Clarke-Steffen, 1997) state secondary analysis involves the use of existing data, collected for a prior study, to pursue a research interest that is distinct from that of the original work; this may be a new research question or an alternative perspective on the original 
question. In this respect, secondary analysis differs from systematic reviews and meta-analyses of qualitative studies, which aim instead to compile and assess the evidence relating to a common concern or area of practice (Popay, Rogers and Williams, 1998).

The Secondary data were obtained from Director General. GTK (Teacher and Education Staff), Ministry of Education and Culture (Dapodik 31 December 2018, processed by the Directorate General of GTK) and PDSPK (Center for data and statistics on education and culture, Secretariat General, Ministry of Education and Culture (Dapodik 31 December 2018). Data analysis techniques are more descriptive, in the sense that they are presented in the form of descriptive statistical tables and then analysed qualitatively to express findings and suggest alternative ways of solving problems.

\section{Results and Discussion}

Based on Dapodik as of December 31, 2018 (processed by the Directorate General of GTK, Ministry of Education and Culture), it is known that the number of teachers there is currently this reached 116,343 teachers, consisting of in-public Vocational Schools amounted to 62,105 teachers and at private VHS amount to 54,238 teachers. The amount an ideal 207,604 teachers, consisting above: at state vocational schools are 88,091 teachers and in private VHS are 119,513 teachers. The number of teachers currently available is smaller compared to the ideal number of teachers. This specialization teacher needs vocational in the category of shortages. Lack of specialization teachers in public VHS as many as 27,164 teachers, while in Private VHS are 66,378 teachers.

1. The Needs of Specialization Vocational Teacher Numbers by Province.

The provinces of West Java, Central Java, and East Java are three provinces which have many needs of teachers.

Table.3 Distribution of Current Vocational Specialization Teachers, Ideal Number of Teachers, Number of

Teacher Needs (+/-) by Province and School Status, 2018.

\begin{tabular}{|c|c|c|c|c|c|c|c|}
\hline \multicolumn{4}{|l|}{ Public VHS } & \multicolumn{4}{|l|}{ Private VHS } \\
\hline Province & $\begin{array}{l}\text { The } \\
\text { number of } \\
\text { available } \\
\text { teachers }\end{array}$ & $\begin{array}{l}\text { The ideal } \\
\text { number } \\
\text { of } \\
\text { teachers }\end{array}$ & $\begin{array}{l}\text { The } \\
\text { number of } \\
\text { need of } \\
\text { teachers }\end{array}$ & Province & $\begin{array}{l}\text { The } \\
\text { number of } \\
\text { available } \\
\text { teachers }\end{array}$ & $\begin{array}{l}\text { The ideal } \\
\text { number } \\
\text { of } \\
\text { teachers }\end{array}$ & $\begin{array}{l}\text { The } \\
\text { number of } \\
\text { need of } \\
\text { teachers }\end{array}$ \\
\hline West Java & 6.182 & 10.655 & -4601 & West Java & 12236 & 31522 & $\begin{array}{l}-19492 \\
\end{array}$ \\
\hline East Java & 7916 & 12173 & -4303 & Central Java & 10632 & 21251 & -10834 \\
\hline Central Java & 6432 & 9643 & -3401 & East Java & 8426 & 18486 & -10228 \\
\hline $\begin{array}{l}\text { South } \\
\text { Sulawesi }\end{array}$ & 2757 & 4003 & -1364 & Banten & 2589 & 7169 & -4629 \\
\hline $\begin{array}{l}\text { North } \\
\text { Sumatra }\end{array}$ & 3877 & 5131 & -1364 & $\begin{array}{l}\text { North } \\
\text { Sumatra }\end{array}$ & 3534 & 7697 & -4242 \\
\hline Banten & 1467 & 2577 & -1321 & $\begin{array}{l}\text { D.K.I } \\
\text { Jakarta }\end{array}$ & 3344 & 6622 & -3408 \\
\hline $\begin{array}{l}\text { South } \\
\text { Sumatra }\end{array}$ & 1772 & 2535 & -795 & Lampung & 1992 & 3489 & -1517 \\
\hline Lampung & 1729 & 2479 & -774 & $\begin{array}{l}\text { South } \\
\text { Sulawesi }\end{array}$ & 986 & 2269 & -1331 \\
\hline $\begin{array}{l}\text { West } \\
\text { Kalimantan }\end{array}$ & 1241 & 1896 & -667 & $\begin{array}{l}\text { South } \\
\text { Sumatra }\end{array}$ & 870 & 2068 & -1214 \\
\hline $\begin{array}{l}\text { South } \\
\text { Kalimantan }\end{array}$ & 1166 & 1736 & -585 & Bali & 880 & 1946 & -1095 \\
\hline $\begin{array}{l}\text { Central } \\
\text { Sulawesi }\end{array}$ & 1020 & 1585 & -575 & $\begin{array}{l}\text { D.I. } \\
\text { Yogyakarta }\end{array}$ & 1163 & 2189 & -1059 \\
\hline $\begin{array}{l}\text { East } \\
\text { Kalimantan }\end{array}$ & 1337 & 1890 & -562 & Riau & 1004 & 1903 & -911 \\
\hline $\begin{array}{l}\text { East Nusa } \\
\text { Tenggara }\end{array}$ & 1811 & 2339 & -550 & $\begin{array}{l}\text { East Nusa } \\
\text { Tenggara }\end{array}$ & 763 & 1590 & -845 \\
\hline $\begin{array}{l}\text { West } \\
\text { Sumatra }\end{array}$ & 2628 & 3126 & -550 & $\begin{array}{l}\text { East } \\
\text { Kalimantan }\end{array}$ & 628 & 1428 & -808 \\
\hline $\begin{array}{l}\text { West Nusa } \\
\text { Tenggara }\end{array}$ & 1693 & 2214 & -537 & $\begin{array}{l}\text { North } \\
\text { Sulawesi }\end{array}$ & 455 & 1009 & -577 \\
\hline $\begin{array}{l}\text { North } \\
\text { Sulawesi }\end{array}$ & 1186 & 1698 & -536 & $\begin{array}{l}\text { West Nusa } \\
\text { Tenggara }\end{array}$ & 563 & 1069 & -509 \\
\hline
\end{tabular}




\begin{tabular}{|c|c|c|c|c|c|c|c|}
\hline \multicolumn{4}{|l|}{ Public VHS } & \multicolumn{4}{|l|}{ Private VHS } \\
\hline Province & $\begin{array}{l}\text { The } \\
\text { number of } \\
\text { available } \\
\text { teachers }\end{array}$ & $\begin{array}{l}\text { The ideal } \\
\text { number } \\
\text { of } \\
\text { teachers }\end{array}$ & $\begin{array}{l}\text { The } \\
\text { number of } \\
\text { need of } \\
\text { teachers }\end{array}$ & Province & $\begin{array}{l}\text { The } \\
\text { number of } \\
\text { available } \\
\text { teachers }\end{array}$ & $\begin{array}{l}\text { The ideal } \\
\text { number } \\
\text { of } \\
\text { teachers }\end{array}$ & $\begin{array}{l}\text { The } \\
\text { number of } \\
\text { need of } \\
\text { teachers }\end{array}$ \\
\hline Riau & 1985 & 2455 & -489 & $\begin{array}{l}\text { West } \\
\text { Sumatra }\end{array}$ & 469 & 900 & -440 \\
\hline Bali & 1418 & 1841 & -464 & $\begin{array}{l}\text { West } \\
\text { Kalimantan }\end{array}$ & 468 & 885 & -421 \\
\hline $\begin{array}{l}\text { D.K.I } \\
\text { Jakarta }\end{array}$ & 1373 & 1754 & -455 & Riau Islands & 306 & 646 & -346 \\
\hline $\begin{array}{l}\text { D.I. } \\
\text { Yogyakarta }\end{array}$ & 1548 & 1878 & -390 & $\begin{array}{l}\text { Central } \\
\text { Sulawesi }\end{array}$ & 290 & 631 & -344 \\
\hline $\begin{array}{l}\text { Southeast } \\
\text { Sulawesi }\end{array}$ & 1037 & 1382 & -355 & $\begin{array}{l}\text { South } \\
\text { Kalimantan }\end{array}$ & 320 & 609 & -290 \\
\hline Bengkulu & 883 & 1192 & -322 & Jambi & 319 & 582 & -266 \\
\hline Jambi & 1374 & 1677 & -322 & $\begin{array}{l}\text { North } \\
\text { Maluku }\end{array}$ & 137 & 389 & -252 \\
\hline Papua & 783 & 1066 & -289 & $\begin{array}{l}\text { West } \\
\text { Sulawesi }\end{array}$ & 171 & 417 & -249 \\
\hline $\begin{array}{l}\text { West } \\
\text { Sulawesi }\end{array}$ & 606 & 870 & -273 & Papua & 319 & 565 & -247 \\
\hline $\begin{array}{l}\text { Central } \\
\text { Kalimantan }\end{array}$ & 1019 & 1275 & -269 & $\begin{array}{l}\text { Southeast } \\
\text { Sulawesi }\end{array}$ & 145 & 356 & -213 \\
\hline Maluku & 682 & 908 & -234 & Maluku & 170 & 326 & -157 \\
\hline $\begin{array}{l}\text { North } \\
\text { Maluku }\end{array}$ & 360 & 563 & -205 & $\begin{array}{l}\text { Central } \\
\text { Kalimantan }\end{array}$ & 192 & 293 & -103 \\
\hline Riau Islands & 567 & 756 & -193 & Aceh & 280 & 371 & -91 \\
\hline $\begin{array}{l}\text { Bangka } \\
\text { Belitung } \\
\text { Islands } \\
\end{array}$ & 556 & 733 & -178 & $\begin{array}{l}\text { Bangka } \\
\text { Belitung } \\
\text { Islands } \\
\end{array}$ & 158 & 234 & -83 \\
\hline Gorontalo & 626 & 775 & -152 & Bengkulu & 178 & 236 & -62 \\
\hline West Papua & 372 & 520 & -151 & West Papua & 127 & 176 & -49 \\
\hline Aceh & 2397 & 2427 & -55 & Gorontalo & 94 & 130 & -36 \\
\hline $\begin{array}{l}\text { North } \\
\text { Kalimantan }\end{array}$ & 301 & 337 & -37 & $\begin{array}{l}\text { North } \\
\text { Kalimantan }\end{array}$ & 30 & 60 & -30 \\
\hline Unknown & 4 & 2 & 2 & & & & \\
\hline Total & 62.105 & 88.091 & -27.164 & Total & 54.238 & 119.513 & -66.378 \\
\hline
\end{tabular}

2. The Needs of Specialization Vocational Teacher Numbers according to the areas of expertise.

From the number of vocational specializations needs by expertise, it still shows a striking gap. All areas of expertise in public and private vocational schools experience a shortage of teachers. Technology and Engineering, Information and Communication Technology, Business and Management are three areas of expertise that many teachers lack. This happens in public and private Vocational High School (Table 5). 
Table 4. Distribution of Current Vocational Specialization Teachers, Ideal Number of Teachers, Number of Teacher Needs (+/-) according to the areas of expertise, in 2018.

\begin{tabular}{|c|c|c|c|c|c|c|c|c|c|}
\hline \multicolumn{5}{|c|}{ Public VHS } & \multicolumn{5}{|c|}{ Private VHS } \\
\hline No. & $\begin{array}{l}\text { Areas of } \\
\text { expertise }\end{array}$ & $\begin{array}{c}\text { The } \\
\text { number } \\
\text { of } \\
\text { available } \\
\text { teachers }\end{array}$ & $\begin{array}{c}\text { The } \\
\text { ideal } \\
\text { number } \\
\text { of } \\
\text { teachers }\end{array}$ & $\begin{array}{c}\text { The } \\
\text { number } \\
\text { of } \\
\text { teacher } \\
\text { needs } \\
(+/-)\end{array}$ & No. & $\begin{array}{l}\text { Areas of } \\
\text { expertise }\end{array}$ & $\begin{array}{c}\text { The } \\
\text { number } \\
\text { of } \\
\text { available } \\
\text { teachers }\end{array}$ & $\begin{array}{c}\text { The } \\
\text { ideal } \\
\text { number } \\
\text { of } \\
\text { teachers }\end{array}$ & $\begin{array}{c}\text { The } \\
\text { number } \\
\text { of } \\
\text { teacher } \\
\text { needs } \\
(+/-)\end{array}$ \\
\hline 1. & $\begin{array}{l}\text { Technology and } \\
\text { Engineering }\end{array}$ & 20.072 & 29.744 & -10.268 & 1. & $\begin{array}{l}\text { Technology and } \\
\text { Engineering }\end{array}$ & 14.893 & 38.041 & -23.628 \\
\hline 2. & $\begin{array}{l}\text { Information and } \\
\text { communication } \\
\text { technology }\end{array}$ & 10.285 & 17.039 & -6.769 & 2. & $\begin{array}{l}\text { Information and } \\
\text { communication } \\
\text { technology }\end{array}$ & 11.520 & 29.228 & -17.733 \\
\hline 3. & $\begin{array}{l}\text { Business and } \\
\text { Management }\end{array}$ & 12.710 & 16.640 & -4197 & 3. & $\begin{array}{l}\text { Business and } \\
\text { Management }\end{array}$ & 17.530 & 32.285 & -15.185 \\
\hline 4. & Tourism & 7.130 & 9.024 & -2.043 & 4. & Tourism & 4.615 & 8.510 & -3.926 \\
\hline 5. & $\begin{array}{l}\text { Agribusiness } \\
\text { and } \\
\text { Agrotechnology }\end{array}$ & 6.196 & 7.981 & -1.827 & 5. & $\begin{array}{l}\text { Agribusiness } \\
\text { and } \\
\text { Agrotechnology }\end{array}$ & 3.467 & 7.065 & -3.675 \\
\hline 6. & $\begin{array}{ll}\text { Arts } & \text { and } \\
\text { creative } & \\
\text { industries } & \\
\end{array}$ & 1.976 & 2.765 & -876 & 6. & $\begin{array}{ll}\text { Arts } & \text { and } \\
\text { creative } & \\
\text { industries } & \\
\end{array}$ & 1.037 & 2.040 & -1.012 \\
\hline 7. & Maritime affairs & 2.670 & 3.310 & -649 & 7. & Maritime affairs & 734 & 1.343 & -167 \\
\hline 8. & $\begin{array}{l}\text { Health and } \\
\text { social work }\end{array}$ & 787 & 1.227 & -450 & 8. & $\begin{array}{l}\text { Health and } \\
\text { social work }\end{array}$ & 341 & 735 & -395 \\
\hline 9. & $\begin{array}{l}\text { Energy and } \\
\text { Mining }\end{array}$ & 279 & 361 & -85 & 9. & $\begin{array}{l}\text { Energy and } \\
\text { Mining }\end{array}$ & 101 & 266 & -167 \\
\hline & Total & 62.105 & 88.091 & -27.164 & & Total & 54.238 & 119.513 & -66.378 \\
\hline
\end{tabular}

Not all schools experience teacher shortages, but some schools have an excess of teachers or not a shortage of teachers - not a surplus of teachers (Table 6). Areas of Technology and Engineering is a field of expertise where schools lack a lot of teachers, both in public and private Vocational High School.

Table 5. Percentage of Public VHS/VHS according to the condition of specialization teachers in, 2018.

\begin{tabular}{|l|l|l|l|l|l|}
\hline \multirow{2}{*}{ No. } & \multicolumn{1}{|c|}{$\begin{array}{c}\text { Area Expertise } \\
\text { School }\end{array}$} & & \multicolumn{2}{c|}{ Condition of Specialization Teacher } \\
\cline { 3 - 6 } & & & Shortage & $\begin{array}{c}\text { Sufficient availability of } \\
\text { teachers }\end{array}$ & Surplus \\
\hline 1. & Technology and Engineering & 1.997 & $81,77 \%$ & $10,92 \%$ & $7,31 \%$ \\
\hline 2. & $\begin{array}{l}\text { Information and communication } \\
\text { technology }\end{array}$ & 2.233 & $76,22 \%$ & $15,14 \%$ & $8,64 \%$ \\
\hline 3. & Health and social work & 211 & $69,67 \%$ & $15,64 \%$ & $14,69 \%$ \\
\hline 4. & Arts and creative industries & 243 & $67,49 \%$ & $17,28 \%$ & $15,23 \%$ \\
\hline 5. & Business and Management & 1.510 & $65,56 \%$ & $15,76 \%$ & $18,68 \%$ \\
\hline 6. & Tourism & 835 & $64,55 \%$ & $16,53 \%$ & $18,92 \%$ \\
\hline 7. & Agribusiness and Agrotechnology & 1.152 & $57,20 \%$ & $21,01 \%$ & $21,79 \%$ \\
\hline 8. & Maritime affairs & 546 & $53,11 \%$ & $20,33 \%$ & $26,56 \%$ \\
\hline 9. & Energy and Mining & 100 & $52,00 \%$ & $27,00 \%$ & $21,00 \%$ \\
\hline
\end{tabular}

Source: (Directorate General of GTK, 2018) 
Table 6. Percentage of Private VHS/VHS according to the condition of specialization teachers in, 2018.

\begin{tabular}{|l|l|l|l|l|l|}
\hline \multirow{2}{*}{ No. } & \multicolumn{1}{|c|}{$\begin{array}{c}\text { Area Expertise } \\
\text { School }\end{array}$} & & \multicolumn{2}{c|}{ Condition of Specialization Teacher } \\
\cline { 4 - 6 } & & & Shortage & $\begin{array}{c}\text { Sufficient availability of } \\
\text { teachers }\end{array}$ & Surplus \\
\hline 1. & Technology and Engineering & 4.326 & $91,86 \%$ & $5,92 \%$ & $2,22 \%$ \\
\hline 2. & $\begin{array}{l}\text { Information and communication } \\
\text { technology }\end{array}$ & 5.455 & $86,32 \%$ & $9,99 \%$ & $3,68 \%$ \\
\hline 3. & Arts and creative industries & 186 & $80,11 \%$ & $13,98 \%$ & $5,91 \%$ \\
\hline 4. & Energy and Mining & 68 & $79,41 \%$ & $13,24 \%$ & $7,35 \%$ \\
\hline 5. & Maritime affairs & 255 & $78,04 \%$ & $11,37 \%$ & $10,59 \%$ \\
\hline 6. & Tourism & 1.286 & $77,29 \%$ & $13,92 \%$ & $8,79 \%$ \\
\hline 7. & Health and social work & 1.406 & $77,29 \%$ & $13,92 \%$ & $8,79 \%$ \\
\hline 8. & Business and Management & 4.683 & $77,13 \%$ & $12,53 \%$ & $10,34 \%$ \\
\hline 9. & Agribusiness and Agrotechnology & 587 & $75,13 \%$ & $13,29 \%$ & $11,58 \%$ \\
\hline 3. & & & & \\
\hline
\end{tabular}

3. Meeting Measures Needs of Vocational Specialization Teachers.

The Efforts that have been/are being undertaken by the national government, provincial government, district/city government, schools, even universities in meeting the needs of vocational specialization teachers, but until now, there is still a lack of vocational specialization teachers. These efforts include:

1. Teacher Recruitment of Civil Servants.

National government has the responsibility to organize teacher recruitment of civil servant. In a Circular Letter (SE) of the Minister of Education and Culture and the Head of State Personnel Agency Number 57686 / MPK / 1989 states that "Teachers are civil servants (PNS) who are given the duties, authority, and responsibilities by officials authorized to carry out education in schools (including rights inherent in position). " In the SE explained that a teacher has the duties, authority, responsibilities, and inherent rights to carry out education in school. Teachers who have legally received recognition from the government in the form of a Decree to carry out their duties as an educator. The teacher as a civil servant is financed and gets an official budget from the APBN (State Budget) and APBD (Local Expenditure Budget) covering all the allowances he gets based on certain groups and tenure because his level of office has a regularity.

2. Honorary Teacher.

Based on Government Regulation Number 48 of 2005 the term Non-permanent Teacher is formal in nature and is the choice of administrative standards for mention in public schools. The term Nonpermanent is commonly found in official letters, assignments, and various other official letters in public schools. Another term used and can be said to be non-formal is Honorary Teacher. Honorary Teacher are appointed based on the needs of the education unit by the principal. Appointment of Decree 26 is local, not provincial (governor), let alone State (President). This appointment is conducted through a series of tests conducted by the school. Every school year, GTT / honorary teacher signs a work contract for a certain period, a year, or more according to the needs of the school.

3. Government Employees with Work Agreements (PPPK).

Established Constitution Number 5 of 2014 concerning State Civil Apparatus (ASN), Honorary Workers are replaced by the term Government Employees with Work Agreements (PPPK), namely Indonesian citizens who meet certain conditions, who are appointed based on work agreements for a certain period in order to carry out governmental duties. Thus, the legislation only regulates honorary teachers who are appointed by the Government and work in public schools. Honorary teachers who work in educational units organized by the Government as well as ASN as in the understanding of ASN in Constitution Number 15 of 2014 concerning ASN, ASN is a profession for civil servants and government employees with employment agreements working for government agencies. ASN employees consisting of civil servants and PPPK who are appointed by official supervisors of personnel and assigned tasks in a government position or assigned to other state tasks and are paid according to statutory regulations.

4. Dual Expertise Program (Ministry of Education and Culture, Directorate General of Primary and Secondary Education, Directorate of Vocational High School Development, 2017).

Dual Skills Program is an additional teaching authority program for VHS / AHS teachers who teach certain subjects to become productive subject teachers in vocational schools on certain competency skills that are different from previous skill competencies and are relevant to their educational background. The granting of teaching authority on the new skills package for VHS / AHS teachers is done after the teacher follows the stages of the education and training process (training) through the 
pattern "ON-1 IN-1 ON-2 and IN-2" and ends with the certification of expertise in the Institute Professional Certification (LSP) to obtain certificates of expertise and certification through Teacher Professional Education and Training (PLPG) at LPTK to obtain educator certificates through the pattern "ON-1 IN-1 ON-2 and IN-2" and ends with the certification of expertise in the Institute Professional Certification (LSP) to obtain certificates of expertise and certification through Teacher Professional Education and Training (PLPG) at Educational Personnel Educational Institutions (LPTK) to obtain educator certificates (MoEC, Directorate General of Primary and Secondary Education, no date).

\section{Conclusion.}

In the previous description stated that the needs of teachers specializing in vocational teacher shortages, both in public and private Vocational High School. The shortage of vocational specialization teachers occurs in each province and in the area of expertise. Many factors affect the needs of teachers, including school enrollment, student mutations, student dropouts, the number of hours per week received by students of each particular subject or all subjects, the full teaching load of teachers per week, large classes considered effective to receive a subject, the number of teachers there are, the number of teachers who will retire or quit or for some reason will leave the teaching position, and the type of school and school level that requires teachers.

The results above mention the number of Teacher needs in public vocational schools has a number of 27,164 while private schools are 66,378. The most significant contributor to numbers is on the island of Java, with the province of West Java, which has the greatest need for teachers, both public and private after East Java and Central Java occupy that. Indeed, not all schools experience teacher shortages and even have a teacher surplus. Still, Indonesia's vast territory, of course, many schools in remote areas, will hamper programs from the government to advance VHS.

Teacher Recruitment for Government Employees with Work Agreements (PPPK) which are now being prioritized to meet the needs of vocational specialization teachers. This is related to the improvement of vocational schools in improving the quality and competitiveness of Indonesian Human Resources in the Cooperation between the Ministry of Education and Culture with Higher Education (PT). This can be done because Universities have Higher Education Tridharma, one of which and community service (Constitution Number 12 the Year 2012 About Higher Education). Collaboration with the commitment of lecturers in universities/polytechnics in fulfilling vocational specialization teachers. The strength of this effort is that there are many prospective teachers in universities / polytechnics, while the shortcomings are the prospective teachers lacking the competencies needed by the Business World and the industrial world (DUDI), so it needs to be drilled first.

Establish Ministry of Education and Cultural Cooperation with DUDI. This can be done utilizing people who have technical skills from the business/industry world who train and guide students in improving technical learning skills in vocational high schools. The strength of this effort is that there are many prospective teachers in DUDI, while the disadvantage is that prospective teachers lack pedagogical competencies, so they need to be trained first.

\section{References}

Cannata, M. (2010) 'Understanding the teacher job search process: espoused preferences and preferences in use', Teachers College Record, 112(12), pp. 2889-2934.

Directorate General of GTK, M. (2018) Dapodik as of December 31, 2018 (processed by the Directorate General of GTK, Ministry of Education and Culture). Available at: http://datadapodik.com/info-424-caracek-info-gtk-semester-1-tahun-2018-2019.html.

Donitsa-schmidt, S. and Zuzovsky, R. (2016) 'Quantitative and qualitative teacher shortage and the turnover phenomenon', International Journal of Educational Research. Elsevier Ltd, 77, pp. 83-91. doi: 10.1016/j.ijer.2016.03.005.

García, Emma and Weiss, E. (2019) 'The teacher shortage is real, large and growing, and worse than we thought. The first report in "The Perfect Strom in the Teache Labor Market" series', (April), pp. 1-19.

Hinds, P.S., Vogel, R.J., Clarke-Steffen, L. (1997) 'The possibilities and pitfalls of doing a secondary analysis of a qualitative data set', Qualitative Health Research, 7(3), pp. 408-24.

Ingersoll, R. M. and May, H. (2012) 'The Magnitude, Destinations, and Determinants of Mathematics and Science Teacher Turnover', Educational Evaluation and Policy Analysis, 34(4), pp. 435-464. doi: $10.3102 / 0162373712454326$.

International, E. (2009) 'Literature Review Vocational Education and Training', America, (October), pp. 1-20.

J. King Rice, C. Roelke, D. Sparks, T. K. (2009) 'Piecing together the teacher policy landscape: a policy problem typology', The Teachers College Record, 111(2), pp. 511-546.

Jose Rizal Joesoef, Umi Muawanah, Fahmi Poernamawati, S. M. and Mukhlis, dan I. (no date) 'The Role of SMK in Supporting Regional Economic Growth: An Macroeconomic Analysis'. 
Meng, Q., Zhang, Y. and Lan, X. (2014) 'The Status and Role of Vocational Teacher Education Institutions in Transforming the Vocational Teacher Development Model', Chinese Education \& Society, 47(5), pp. 47-56. doi: 10.2753/CED1061-1932470504.

MoEC, Directorate General of Primary and Secondary Education, D. of V. H. S. D. (no date) Educational Certification Program And Expertise Certification For Teachers Of Vocational Schools / High School. Available at: http://alihfungsi.gtk.kemdikbud.go.id.

MoEC (2006) 'Regulation of the Minister of National Education of the Republic of Indonesia', p. 22.

Munene, I. I. and Ruto, S. J. (2016) 'Does Teacher Availability Matter?-Evidence from Uwezo East Africa Study Data', Journal of Contemporary Issues in Education, 10(1). doi: 10.20355/c5fs3d.

$\mathrm{Ng}$, J. C. (2003) 'Teacher shortages in urban schools: The role of traditional and alternative certification routes in filling the voids', Education and Urban Society, 35(4), pp. 380-398. doi: 10.1177/0013124503255453.

Paulo Santiago (no date) Teacher shortage. Available at: https://oecdobserver.org/news/archivestory.php/aid/431/Teacher_shortage.html.

Popay, J., Rogers, A. and Williams, G. (1998) 'Rationale and standards for the systematic review of qualitative literature in health services research', Qualitative Health Research, 8(3), pp. 341-351. doi: $10.1177 / 104973239800800305$.

Sulaiman, J. et al. (2019) 'OJ-TP Professionalism of Technical Teacher in Vocational Education : Professional Knowledge That Contribute To A Teacher' s Effectiveness', Online Journal for Tvet Practitioners, 4(2), pp. 42-48. doi: doi.org/10.30880/ojtp.00.00.0000.00.0000.

Sutcher, L., Darling-Hammond, L. and Carver-Thomas, D. (2019) 'Understanding teacher shortages: An analysis of teacher supply and demand in the united states', Education Policy Analysis Archives, 27. doi: 10.14507/epaa.27.3696.

Triwiyanto, T., Desi Eri Kusumaningrum, dan I. G. (2017) 'Projected Availability, Needs, and Distribution of Junior High School Teachers in Batu City'.

Yulius, Muhammad Isran, Mardhianda WP, B. A. (2017) 'Vocational Development Policy Roadmap in Indonesia 2017-2025'. 